San Jose State University

SJSU ScholarWorks

Faculty Publications, English and Comparative Literature

$1-1-2009$

\title{
On a Special Copy of Caroline Lamb's Glenarvon Recently Discovered in the Koninklijke Bibliotheek
}

Paul Douglass

San Jose State University, paul.douglass@sjsu.edu

Ria Grimbergen

San José State University

Follow this and additional works at: https://scholarworks.sjsu.edu/eng_complit_pub

Part of the Comparative Literature Commons, and the English Language and Literature Commons

\section{Recommended Citation}

Paul Douglass and Ria Grimbergen. "On a Special Copy of Caroline Lamb's Glenarvon Recently Discovered in the Koninklijke Bibliotheek" The Byron Journal (2009): 151-160. https://doi.org/10.1353/byr.0.0065

This Article is brought to you for free and open access by the English and Comparative Literature at SJSU ScholarWorks. It has been accepted for inclusion in Faculty Publications, English and Comparative Literature by an authorized administrator of SJSU ScholarWorks. For more information, please contact scholarworks@sjsu.edu. 


\title{
On a Special Copy of Caroline Lamb's Glenarvon Recently Discovered in the Koninklijke Bibliotheek
}

\author{
RIA GRIMBERGEN AND PAUL DOUgLASS
}

\begin{abstract}
This essay analyses a recently discovered copy of the first edition of Lady Caroline Lamb's Glenarvon in the Koninklijke Bibliotheek at The Hague filled with annotations and corrections apparently in the hand of its author. This copy shows many of the extensive revisions eventually implemented in the second edition of the novel. Some changes indicated in this special copy were not adopted, however, and a note on the punctuation in a hand not the author's raises the question of whether others edited the work, especially the punctuation. The essay shows how, working with great skill to minimise the labour of resetting type, Lamb appears to have made her text less vulnerable to charges of indecency, blasphemy, and animus towards friends and relations. However, it also shows that the novel's major themes remain substantially unaltered, while the transgressions of Lamb's protagonist, Lady Calantha, are excused as the result of ineluctable passions. The consistency of the substantive alterations and the inconsistency of the punctuational changes suggest that Lamb probably had the final word on revisions.
\end{abstract}

Lady Caroline Lamb's novel Glenarvon was published anonymously by Henry Colburn on 9 May i8I6, just two weeks after Byron had left England amidst tremendous controversy over his separation from his wife and child. An unflattering picture of Whig morality was embodied in this novel, which was, of course, almost universally viewed as a 'kiss-and-tell' fictionalisation of Lamb's rather public liaison with Byron four years earlier. Even before the first I 500 copies were sold Lamb wrote to tell her editor that she had approval from her husband, William, for a revised second edition, and to urge him to sell the remainder of the first as quickly as possible. 'She requested that the editor present the proofs to her and assured him that she would acquaint herself with the correction marks used by printers. ${ }^{2}$ The heavily revised second edition of Glenarvon appeared in June. As John Clubbe first pointed out in 'Glenarvon, Revised and Revisited' (I979), Lamb corrected hundreds of mistakes in language and style, as well as printing errors. She also rewrote whole episodes and added a preface deflecting criticism that the novel was ill-constructed, libellous, slanderous and immoral.

As Clubbe says, Lamb 'carefully revised' the novel 'to eliminate passages that had hurt others or shocked public taste'. 'I am doing every thing I can to stop further mischief', she told Lady Melbourne, her mother-in-law. ${ }^{4}$ The press had treated Glenarvon roughly, complaining that it was composed of 'scenes of seduction and 


\section{Ria Grimbergen and Paul Douglass}

adultery' by a writer who appeared 'to glory in her guilt'.5 One journal even described it hyperbolically as a work of pornography, like John Cleland's Fanny Hill, and no one thought it much better than 'wearisome'. 'Lamb fought back in the preface to the second edition, asserting that her novel had no 'immoral tendency', and as one assesses the changes made in the second and third editions, one notices that she actually gives little ground on the fundamental situations and behaviour of her characters. One would like to know more about the process by which she decided what to cut, amend or add, and who may have pressured her into making certain changes. It is therefore fortunate that one of the co-authors of this essay, Ria Grimbergen, discovered a special copy of Glenarvon in the Koninklijke Bibliotheek (Dutch Royal Library) at The Hague, ${ }^{9}$ one that is filled with annotations and corrections apparently in the hand of Lamb herself. This previously undiscovered record of Lamb's work on her novel shows that she made revisions with great rapidity and skill, though it also raises some perhaps unanswerable questions about the motives behind certain revisions, and about whether others (a copy-editor, her husband?) may have influenced other changes made later when the novel's second edition was published.

All but a handful of the notations in the margins of the text appear to be in Lamb's handwriting. Among the few exceptions is the note on the title-page of Volume I, written in an unfamiliar script rounder than Lamb's: 'I have particularly attended to the punctuation; and beg that in the reprint, it may be copied as now corrected. A. W.' Who may A. W. be? Possibly it is a Mr Walter or Waller, because a third hand has written on page I 47 of Volume I: 'All composed to this but not improved. Mr. Walter [Waller?] has 3 proofs. ${ }^{\text {IO }}$ This remark has been crossed out vigorously. To whom can it be ascribed? How did this book land in the Royal Library? Although such questions concerning this newly discovered copy of Glenarvon remain as yet unanswered, we can nonetheless gain from it numerous insights into the pressures under which Lamb modified her text.

For the second edition, Lamb made well over 2200 individual alterations to her novel of some 150,000 words. In such a large text, it is rather astonishing to note that while the page count of Volume I shrank from 295 to 288, the page counts of Volumes II and III remained exactly the same (390 and 322 respectively). A close look at one page-spread from Volume II will provide a sense of the dexterity with which Lamb made revisions, making the printer's job as easy as possible. In the following facsimile reproduction of pages $158-59$, we can see her making a key deletion (on page 158 ), then giving instructions for how to cope with the typesetting consequences. Lamb here instructs the printer to pull back three lines from page 159 to page 158 , and to bring text back from page I60 to page I59. Since page I60 is the last page of a chapter, no further adjustments were needed in the typesetting. The changes here (to which we shall return below) typify patterns of revision throughout the second edition of Glenarvon.

The most heavily edited of the three volumes of this copy of Glenarvon is the first, which is riddled with handwritten emendations, crossings-out and passages added. Volume I of the Royal Library copy also contains a 'Preface to the Second Edition', 

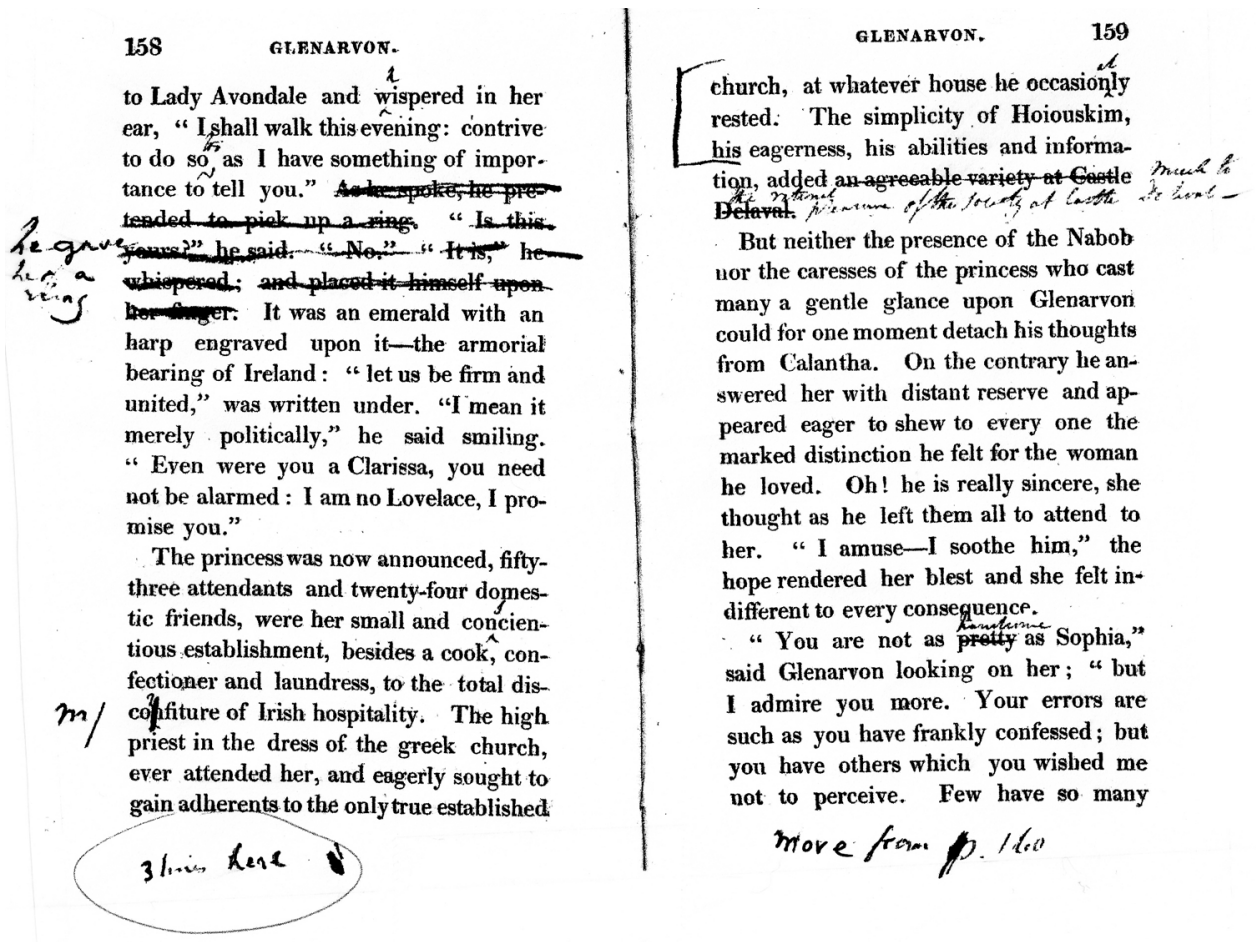

(Reproduced by permission of the Koninklijke Bibliotheek)

which was in fact published in the second edition. The title page of the second volume indicates that it is the second edition of the novel, but the peculiar numbering of the chapters demonstrates that the text is really from the first edition. ${ }^{\text {II }}$ Remarkably, an introduction is also incorporated into the binding - something not found in any of the first three editions, only in the fourth, where it is described somewhat anomalously as the 'Original Introduction'. It seems likely, then, that this copy served as a proof for the second edition - or at least one of the proofs, for many changes that were eventually made in the second edition do not appear here, while some of the corrections made in this copy were not adopted by the printer when the second edition was published.

For example, Lamb's corrections call for an alteration of the motto. The first edition drew its epigraph from Canto 33 of Dante's Inferno: 'Disperato dolor, che il cor mi preme / Gía pur pensando, pria che ne favelle' ('I renew a hopeless despair, that makes my heart still ache / at the thought, before the words follow'). It seems that Lamb wanted to replace this with a (slightly mis-transcribed) line in Latin: 'Contem[p]tu famae contemni virtutem'. This epigraph - 'to despise fame is to despise merit' - is from Book 4 of the Annals of Tacitus. However, it was not adopted for the second edition (which instead prints a modified passage from Voltaire's Zadig). ${ }^{\text {I2 }}$ Nor were the lines from Tacitus used in the third edition, which retained the passage from Voltaire. But the passage from Annals did appear when the fourth edition was published. The choice of Tacitus's comments on fame seems to imply that those who despised Byron's (and 
Lamb's) notoriety missed the important virtues that each also possessed. Whatever the reasons for the change, we can say that the epigraphs from Tacitus and Voltaire both emphasise that Lamb condoned illicit love when the passions demanded it, a principle she found in John Ford's dramas, especially The Broken Heart (1633), whose protagonist, Princess Calantha, provided the name for Lamb's heroine, Lady Calantha Delaval.

In contrast, many other modifications made by Lamb in her notes to this copy of her novel appear intended, as Clubbe notes, to spare her acquaintances and family members the pain of being represented negatively. Calantha originally complained at the end of Volume I: 'Every one smiles on me and seems to love me - the world befriends me she continually thought; yet I am censured and misrepresented. My relations - the only enemies I have - are those who profess to be my friends.' In her notes to the text now in the Royal Library, Lamb excised the phrase 'My relations', for obvious reasons. ${ }^{\text {'3 }}$ And when the second edition was finally published, the entire sentence had been cut.

Another example of Lamb's revisions being apparently motivated by a desire to cause less pain to others is also found towards the end of Glenarvon's first volume. A character known simply as 'a poet' is described in the first edition as follows:

A poet of an emaciated and sallow complexion stood beside her; of him it was affirmed that in apparently the kindest and most engaging manner, he, at all times, said precisely that which was most unpleasant to the person he appeared to praise. This yellow hyena had, however, a heart noble, magnanimous and generous; and even his friends, could they but escape from his smile and his tongue, had no reason to complain. (Glenarvon, I, p. 248; Works, I, p. 87)

The poet Samuel Rogers is here being depicted identifiably for contemporaries. Rogers was cadaverously thin and appeared so emaciated that once when he was emerging from the Roman catacombs a friend turned to him and shook hands, saying to his skeletal friend, 'Good-bye, Rogers'. ${ }^{14}$ In the Royal Library copy of Lamb's novel, the author has crossed out these two offending sentences and made other changes so as to delete the 'hyena' entirely from the scene, giving the sallow poet's lines instead to another character named 'Tremore' (whose name is later spelt in the first edition consistently as 'Fremore', to which the spelling is corrected throughout the second edition). Lamb thus took out the most egregious elements of the parody, yet nonetheless retained certain characteristics of the acerbically witty Rogers in Fremore's character, though turning him from cadaverously thin into a man of 'huge circumference' (Glenarvon, I, p. 20I; Works I, p. 7I). And Lamb's handwritten annotations go on to show the clear intention of removing the ridicule of Rogers as a cadaverous, sharp-tongued fellow from the novel entirely by removing another allusion in Volume I - 'the dead, I mean the sick poet' (Glenarvon, I, p. 249; Works, I, p. 87) - and by deleting the only other reference to him, which appeared in Volume III: 'The dead, or yellow poet was twice carried by mistake to the grave' (Glenarvon, III, p. 30I; Works, I, p. 346).

Lamb softened other portraits in the novel, including that of Lord Avondale, widely believed to be modelled upon Lamb's husband. Lord Avondale is described as, by nature, a quiet man who was unfortunately 'admired, flattered, sought after; and 
the strong temptation to which his youth had thus early been exposed, had, in some measure, shaken his principles and perverted his inclinations', according to the first edition. In the Royal Library text, Lamb crosses out 'perverted his inclinations' and puts instead 'inflamed his imagination' (Glenarvon, I, p. 85; Works, I, p. 32). A similar sort of revision would be required of the portrait of Lord Avondale in Chapter 17 of Volume I. Here Lamb describes how Calantha's eventual downfall is being prepared by Avondale from the first months of their marriage. Isolated from the social world, the childlike Calantha adores her handsome and distinguished husband, a generous man with positive qualities. Exactly because of his kindness he is not capable of giving guidance to his young bride and correcting her. Calantha and her husband differ in their religious convictions. Avondale loves to have discussions with his deeply religious wife about points of doctrine and questions of morality, and he opens an unknown world of ambiguity for her, unaware of the danger to her moral principles. In the first edition the upright Avondale appears to have demonic traits that are removed in revision:

Before this period, her eyes had never even glanced upon the numerous pages which have unfortunately been traced by the hand of profaneness and impurity; even the more innocent fictions of romance had been withheld from her; and her mother's precepts had, in this respect, been attended to by her with sacred care. Books of every description were now, without advice, without selection, thrown open before her; horror and astonishment at first retarded the course of curiosity and interest: - Lord Avondale smiled; and soon the alarm of innocence was converted into admiration at the wit, and beauty with which some of these works abounded. Care is taken when the blind are cured, that the strong light of day should not fall too suddenly upon the eye; but no caution was observed in at once removing from Calantha's mind, the shackles, the superstitions, the reserve, the restrictions which overstrained notions of purity and piety had imposed.

In the Royal Library Glenarvon, Lamb makes the smiling Avondale disappear altogether and settles responsibility for the loss of her innocence squarely on Calantha by changing the passage as follows:

Before this period, her eyes had never even glanced upon the numerous pages which have unfortunately been traced by the hand of unrestrained inquiry and daring speculation; even the more innocent fictions of romance had been withheld from her; and her mother's precepts had, in this respect, been attended to by her with sacred care. Books of every description, the works of Historians, Philosophers and Metaphysicians, were now, eagerly devoured by her; astonishment at first retarded the course of curiosity and interest: and soon the surprise of innocence was converted into admiration at the wit, and beauty with which some of these works abounded. Care is taken when the blind are cured, that the strong light of day should not fall too suddenly upon the eye; but what avail was caution to Calantha - ever in extremes she threw off at once the shackles, the superstitions, the reserve, the restrictions which perhaps overstrained notions of purity and piety had imposed. (Glenarvon, I, p. I42-43; Works, I, p. 51, emphasis ours)

In general, Avondale's portrait is altered so that Calantha is more culpable and he less so. An example of this softer treatment of Avondale is found in Chapter 26 of 


\section{Ria Grimbergen and Paul Douglass}

Volume II, which opens with a paragraph about how lack of love in a marriage, and a man's neglect and stern treatment of his wife in such circumstances, can only exacerbate her deceit. How could it be that Lord Avondale remains ignorant of his wife's adultery? In the Royal Library copy of the novel, Lamb adds a paragraph to emphasise Avondale's nobility and defend him from the charge of being stupid or unperceptive: 'How different was he in mind, in person, and heart from other men. His very nobleness of soul prevented him from conceiving what some perhaps had soon observed, and wounded pride estranged him from a woman who now appeared avowedly to shun his society' (Glenarvon, II, p. 245; Works, I, p. I92). Lamb's revisions clearly seem intended to exonerate Avondale.

Lamb's annotations also seem to be rationalising Calantha's behaviour as the consequence of a passion she can neither control nor transcend. The ineluctable forces impinging upon Calantha are symbolised, perhaps, in the ring-gift ceremony that we have already seen Lamb softening in the facsimile of pages $158-59$ of the Royal Library text given above. The original reads:

Lord Glenarvon came to Lady Avondale and whispered in her ear, 'I shall walk this evening: contrive to do so as I have something of importance to tell you.' As he spoke, he pretended to pick up a ring. 'Is this yours?' he said. 'No.' 'It is,' he whispered; and placed it himself upon her finger.

Lamb replaces all of this with the much simpler 'He gave her a ring' (Glenarvon, II, p. I 58 ; Works, I, p. I59).

Who or what induced Lamb to change this scene, downplaying its intimacy and the wittiness of the giver? Byron described a similar incident for Lady Melbourne, except that in his account Lamb presents herself with a ring, a marriage ring, and insists he put it on her finger. ${ }^{15}$ By making the scene more distant, less intimate, Lamb seems to back away from the carnality of the relationship. Similarly, another revision to the Royal Library's copy of the novel alters this description of Glenarvon's passion: 'As he spoke, he again pressed her to his bosom, and his tears fell over her.' In her handwritten emendations, Lamb alters this to: 'As he spoke his tears fell upon her hand' (Glenarvon, II, p. 228; Works, I, p. I86). Elsewhere, 'her lover' is changed into 'the lover'. ${ }^{16}$ As these revisions show, Lamb sought to diminish the carnality but left plenty of evidence of it. But Lamb's reductions in the description of heated passion were much more drastic in the actual second edition. For example, none of the following changes are written into the Royal Library text: 'lust' to 'passion', 'whirlwinds of passion' to 'whirlwinds' and 'chaste' to 'pure'. Yet such changes are found throughout the second edition. $^{17}$

These changes could be interpreted as an attempt by Lamb to make her novel less vulnerable to the charge of 'pornography', although by comparison to other books of the day the descriptions she cut seem tame. Sentimental poetry, like the Gothic novel and drama generally, was rife with sexuality, as we can observe in Charlotte Dacre's Hours of Solitude (1802): 
Reclining here, beneath the shade

Sleeps a languid, half-dress'd maid;

There, a youth, whose varying cheek,

Seems disorder to bespeak. $(\mathrm{I}, 7)^{18}$

Dacre gives her reader the 'falt'ring sigh, / Voluptuous eye, / And palpitating heart' of 'rapture as it flow'd' (I, 23, I IO), and influenced other writers, such as Byron, whose Fugitive Pieces (1806) portrays lovers seeing 'each other panting, dying, / In love's extatic posture lying, / Grateful to feeling, as to sight' ('To Mary', 45-48).

If the supposed lustiness of the relationship between Glenarvon and Calantha is diminished in the revisions to the Royal Library's copy of Glenarvon, and almost expunged in the second edition of the novel as published, Lamb ultimately resisted changing Lady Calantha's fundamental situation, stubbornly insisting that her protagonist stood at the mercy of forces beyond her control. In the first edition, when Lord Avondale departs, the novel's narrator suggests:

How happy some may imagine - how happy Calantha must have felt now that Lord Avondale was gone. Far from it. She for the first time felt remorse. His departure filled her with gloom. (emphasis ours)

In the copy in the Royal Library, Lamb modifies this passage extensively without changing its essential message. Instead of feeling 'remorse', Calantha is described as seeing 'her conduct in its true light', and after the concluding word 'gloom' Lamb adds: 'Every little act of kindness he had once shew[e]d her recurred all his manly virtues, his open unsuspicious nature.' Later in this same chapter, Calantha considers why she seems to have two consciousnesses: one with no intention of leaving Avondale, the other completely under the spell of Glenarvon, so that leaving is natural and obvious. So long as 'Lord Glenarvon was near her, no remorse obtruded - no fear occurred she formed no view for the future'. Here Lamb only slightly softens Calantha's defiance by replacing 'no remorse' with 'only momentary fits of remorse' and 'no fear' with 'no lasting fear' (Glenarvon, II, p. 248; Works, I, p. I93).

In her handwritten revisions to a similar passage in Volume III, Lamb seems to bow to pressure to make Calantha more obviously culpable. After a passage about guilty love, the power of passion and the torture of feelings of guilt and of anger at being judged by people alien to such feelings, Lamb had published this in the first edition: 'There are trials, which human frailty cannot resist - there are passions implanted in the heart's core, which reason cannot subdue; and God himself compassionates, when a fellow-creature refuses to extend to us his mercy or forgiveness.' In the Royal Library's Glenarvon, Lamb has rewritten this to the opposite effect (and the changes were implemented when the second edition was published):

There is no trial which human frailty cannot resist - if supported by religion - there is no passion implanted in the heart's core, which reason cannot subdue, if we call upon our God to assist us; but, when unsupported by his strength, every temptation that assails us may overcome us, and the remembrance of our own weakness should teach us to be humble in ourselves. (Glenarvon, III, pp. 4-5; Works, I, p. 245; emphasis ours) 


\section{Ria Grimbergen and Paul Douglass}

This change, which might seem to lower Calantha in our opinion, is balanced by Lamb's intention, made clear in these handwritten emendations, to make her protagonist more sympathetic. The Royal Library Glenarvon also shows Lamb's decision to provide Calantha, in the second edition, with a Roman Catholic background, and this is undoubtedly connected to the idea of confession and expiation. In every edition of the novel Calantha confesses on her deathbed her own helpless guilt and failure as a member of the nobility:

'From the deep recesses of a guilty, yet not humble heart, in the agony and the hopelessness of despair,' said Calantha, 'I acknowledge before God and before man, that for me there is no excuse. I have felt, I have enjoyed every happiness, every delight, the earth can offer. Its vanities, its pleasures, its transports have been mine; and in all instances I have misused the power with which I have been too much and too long entrusted. [...] Yet when they read my history - if amidst the severity of justice which such a narrative must excite, some feelings of forgiveness and pity should arise, perhaps the prayer of one, who has suffered much, may ascend for them, and the thanks of a broken heart be accepted in return.' (Glenarvon, III, pp. I45-46; Works, I, pp. 292-93)

The phrase 'broken heart' (in an allusion to Ford's play) is repeated many times in Glenarvon. For example, when Elinor St Clare rides her horse over the cliffs of Heremon she says: 'Peace to the broken hearts' (Glenarvon, III, p. 294; Works, I, p. 344). Though, as Lamb would make perfectly clear, Calantha is herself to blame, she is also portrayed as a victim. When she finally dies in Volume III, Lord Avondale sheds bitter tears. Lamb added a long paragraph at this point to the Royal Library text, and this revision was published in the second and every subsequent edition of Glenarvon:

And did she thus die some may perhaps exclaim unpunished for her crime? Did she not live to feel its consequences in all their magnitude and bitterness - to hide under smiles of levity the anguish of her soul - to mask under the appearance of pride and insensibility, the remorse, the terror, the despair, she felt - to receive from strangers unmerited kindness - to hear from malice all that she too well deserved? Did she not linger on to see the husband she adored reproached by the cold and stern, for his mercy to herself - to trace in its countenance the bitterness of a proud but injured spirit struggling to conceal its sufferings and its wrongs, perishing by slow degrees, of the cruellest of all maladies - disappointment, regret, injured honour, and blasted happiness? Oh did the God who made her, in commiseration for what she had already felt, spare her his trial? - He did in mercy; and on a bed of death, she lay insensible to the present, as to the past. (Glenarvon, III, pp. I63-64; Works, I, p. 299)

Lamb has responded to her critics by underscoring the idea that God does indeed have 'mercy' upon guilty Calantha, and spares her.'

The Royal Library's copy of Glenarvon contains a large number of authorial changes that correspond to the changes made to the novel in its second edition, but not all do so, by any means. As we have already seen, the diminishing of the sexual relationship between Glenarvon and Calantha is seldom found in Lamb's annotations to the Royal Library text. And in those annotations, which may have been the first pass at revising 
her novel, Lamb's 'God' remains 'God', whereas in the second edition He has been replaced by the more Roman Catholic 'Father', consistent with the Roman Catholic identity Calantha receives. ${ }^{20}$ The satanic character of Glenarvon is weakened in the second edition - but not in the Royal Library's copy of the novel, which apparently only served to a certain extent as the revised copy for the second edition to follow. Did Lamb later introduce other major changes of her own volition or was she 'encouraged' to do so? Did she herself or someone else rewrite the text? Are all improvements from her hand? The consistency of the revisions, and also the inconsistency of some of the changes in punctuation, suggest that she had the final word, but perhaps more evidence is out there that will help us reach a conclusion.

Dutch Byron Society and San José State University

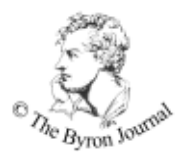

I See Lamb's letter to Henry Colburn of May-June i8I6, in The Whole Disgraceful Truth: Selected Letters of Lady Caroline Lamb, ed. by Paul Douglass (New York and London: Palgrave, 2006), p. I5I.

2 Paul Douglass, Lady Caroline Lamb: A Biography (New York and London: Palgrave, 2004), p. I95.

3 John Clubbe, 'Glenarvon Revised and Revisited', The Wordsworth Circle, ro (1979), pp. 205-17 (p. 209). Professor Clubbe generously shared with Douglass copies of some of Lamb's letters and notes from his essay on Glenarvon's revisions while Douglass was writing a biography of Lamb and editing her works with Leigh Wetherall Dickson, for which he is deeply grateful.

4 Lady Caroline Lamb to Lady Melbourne, n.d. (after 9 May I8I6), British Library, Add. MS 45546 f.9I-92.

5 Anonymous, Review of Glenarvon, The British Critic, 5 (June i8I6), pp. 627-3I (p. 628).

6 Anonymous, Review of Glenarvon, Theatrical Inquisitor, 9 (August 1816), pp. I22-25 (p. 125).

7 Anonymous, Review of Glenarvon, Monthly Review, 80 (June I8I6), pp. 217-I8 (p. 218).

8 See Appendix A, The Works of Lady Caroline Lamb, ed. by Paul Douglass and Leigh Wetherall Dickson, 3 vols (London: Pickering \& Chatto, 2009), I, pp. 353-56 (p. 353).

9 Lady Caroline Lamb, Glenarvon, 3 vols (London: Henry Colburn, I8I6), Koninklijke Bibliotheek, shelf-mark 89IC5 I.

Io Some of the numerous changes in punctuation to Glenarvon could have been made by 'A. W.', since it is hard to tell which hand puts in a comma, or crosses one out and substitutes a semi-colon, for example.

II In the first edition of Glenarvon there are numerous chapter numbering errors. Volume I numbers chapters from I to 33, but skips Chapter 9 (an error that persists in all subsequent editions by Colburn). Volume II numbers chapters from I to 38 , committing three typographical errors with Roman numerals, so that Chapter 26 (XXVI) is accidentally numbered Chapter 24 (XXIV), Chapter 27 (XXVII) is numbered Chapter 26 (XXVI) and Chapter 36 (XXXVI) is numbered Chapter 34 (XXXIV). Most of these errors were corrected in subsequent editions, and so was the most egregious of the errors: instead of beginning again from Chapter I, Volume III starts at Chapter 72 and ends with Chapter I06. This distinctive feature makes it virtually certain that the copy of the novel in the Koninklijke Bibliotheek is of the first edition of May I8I6.

I2 The motto (or epigraph) for the second edition of Glenarvon was: 'Les passions sont les vents qui enflent les voiles du vaisseau: elles le submergent quelquefois, mais sans elles il ne pourrait voguer. Tout est dangereux ici-bas, et tout est nécessaire.' (The passions are the winds which fill the sails 


\section{Ria Grimbergen and Paul Douglass}

of the vessel: they submerge her sometimes, but without them she could not sail. Everything is dangerous, here below, and everything is necessary.) This text is a modification of a passage from Voltaire's Zadig, Chapter 22: “"Ce sont les vents qui enflent les voiles du vaisseau”, repartit l'ermite: "elles le submergent quelquefois; mais sans elles il ne pourrait voguer. La bile rend colère et malade; mais sans la bile l'homme ne saurait vivre. Tout est dangereux ici-bas, et tout est nécessaire".' ('The passions are the winds which fill the sails of the vessel', resumed the hermit. 'They submerge her sometimes, but without them, she could not sail. Phlegm, indeed, makes men peevish and sick; but then there is no living without it. Everything is dangerous, here below, and everything is necessary.') We are indebted to Néhal Abuelata for her assistance in translating the passage in French from Voltaire's Zadig. For further details on the mottos/epigraphs to Glenarvon, see The Works of Lady Caroline Lamb, I, p. 363.

I3 Glenarvon, Koninklijke Bibliotheek, shelf-mark 89 I C5I, vol. I, p. 286. All volume and page references to Glenarvon are to this copy, which is identical to the first edition. Supplementary volume and page references for quotations from this copy of the novel are also, wherever possible, given to The Works of Lady Caroline Lamb, hereafter Works (in this instance, vol. I, p. 99). Quotations from the second, third and fourth editions of the novel are referenced to Works (which collates textual variants in its notes). Subsequent references will be given after quotations in the main text.

I4 M. Joyce, My Friend H: John Cam Hobhouse, Baron Broughton of Broughton de Gyfford (London: John Murray, I948), p. 50.

I5 Byron's letter to Lady Melbourne of 5 April I8I3, in BLJ, III, p. 35 .

I6 See Works, I, pp. I86 and 43I, n. I86j.

I7 See Works, I, pp. 425 , notes I48b-I48d.

I8 Charlotte Dacre, Hours of Solitude, 2 vols (London: D. N. Shury, I805).

I9 See Works, I, p. 447, n. 299b. Interestingly, in the annotations to the Royal Library text, 'insensible to the present' is replaced by 'insensible to her husband' (see Works, I, p. 45I, n. I3).

20 See, for example, Works, I, pp. 267 and 444, n. $267 \mathrm{~b}$, where the phrase 'Oh, God of mercy' is altered to 'Oh Father of mercy'. 
Copyright of Byron Journal is published by Liverpool University Press, and its content may not be copied or emailed to multiple sites or posted to a listserv without Liverpool University Press's express written copyright permission. However, users may print, download, or email articles for individual use. 